\title{
Effect of Different Thermal Schedules on Ductility of Microalloyed Steel Slabs during Continuous Casting
}

\author{
Liu Yang $1,2,3,4$, Yang $\mathrm{Li}^{1,2,3, *(\mathbb{D})}$, Zhengliang Xue ${ }^{1,2,3}$ and Changgui Cheng ${ }^{1,2,3}$ \\ 1 The State Key Laboratory of Refractories and Metallurgy, Wuhan University of Science and Technology, \\ Wuhan 430081, China; willows1987@sina.com (L.Y.); xuezhengliang@wust.edu.cn (Z.X.); \\ ccghlx@wust.edu.cn (C.C.) \\ 2 Key Laboratory for Ferrous Metallurgy and Resources Utilization of Ministry of Education, \\ Wuhan University of Science and Technology, Wuhan 430081, China \\ 3 Hubei Provincial Engineering Technology Research Center of Metallurgical Secondary Resources, \\ Wuhan University of Science and Technology, Wuhan 430081, China \\ 4 Steelmaking Plant of Wuhan Iron and Steel Corporation Limited, BAOWU Steel Group, \\ Wuhan 430083, China \\ * Correspondence: liyang@wust.edu.cn; Tel.: +86-027-6886-2651
}

Received: 5 December 2018; Accepted: 26 December 2018; Published: 4 January 2019 updates

\begin{abstract}
Ductility is the important indicator of transverse surface cracking susceptibility of slabs of microalloyed steels during continuous casting. Welding structure steel HG785 is selected to study the effect of different thermal schedule on ductility of microalloyed steel slabs during continuous casting in this paper. Surface Structure Control (SSC) cooling process parameters of HG785 microalloyed steel were confirmed by the aid of thermomechanical simulation experiment of Gleeble 3500. Results of tensile tests show that the ductilities of slabs under traditional thermal schedule and temperature fluctuation thermal schedule are very low in the III brittleness zone, and the reductions of area reach $29.7 \%$ and $26.0 \%$ at $800{ }^{\circ} \mathrm{C}$, respectively. The ductility of slabs under SSC thermal schedule is obviously improved, since the pro-eutectoid ferrite film and aggregation of precipitates along the austenite grain boundary has not been discovered.
\end{abstract}

Keywords: microalloyed steel; thermal schedules; precipitates; ductility; SSC

\section{Introduction}

Due to the solid solution strengthening effect of carbonitride precipitation, a good combination of strength, ductility, and welding performance of the microalloyed steels can be achieved [1-5]. However, transverse surface cracks often occur during continuous casting of microalloyed steels, especially transverse corner cracks, and the phenomenon of broken edges and cracking often occur during the hot rolling process [6-8]. These can only be solved by grinding and cutting the corner in continuous casting and cutting the edge in rolling process, which seriously reduce the yield of final steel. How to eliminate the surface defects and improve the surface quality of continuous casting has become one of the main research topics for metallurgical workers.

A large number of studies have shown that the corner transverse cracks of microalloyed steel during continuous casting are related to the precipitates along austenite grain boundary and solid phase transition in straightening process [9-11]. In order to eliminate the transverse cracks, a weak cooling of spray cooling with air and water adopted in secondary cooling zone were proposed by some scholars [12], which avoids the effect of phase transformation and carbonitrides precipitation in straightening process on deterioration of ductility. Walmag et al. [13] and Kato et al. [14] present Surface Structure Control (SSC process), which can eliminate the ferrite film and chain carbonitrides 
precipitation around the austenite grain boundary on the surface of slab, and thus avoid the formation of corner cross cracks. For SSC thermal process, the surface temperature of the slab was reduced below $\mathrm{Ar}_{3}$ and the transformation of $\gamma$ (Austenite) to $\mathrm{F}$ ( $\alpha$-Ferrite) is finished with intense cooling at the mold exit, and then recovered though solidification, physical and latent heating of liquid steel in the core of the slab.

At present, SSC technology has not been widely applied [15] and the key restraining factor is the unclear specific process parameters. The influence of SSC technology on the grain size and precipitate position of austenite has been disputed. Kato et al. [14] believed that the size and position of the austenite grain boundary did not change before and after the intense cooling. Suzuki et al. [16] believed that the reconstructed austenite grains only shifted, while the grain size did not change. Owing to a low temperature stage in the thermal schedule of the SSC process, Walmag et al. [13], Lee et al. [17], and Ma et al. [18] believed that the growth time of original austenite grains was reduced, and the new austenite grains were nucleated around the ferrite grain boundary during the process of re-austenite transformation, and the newly formed austenite grains became smaller. Du et al. [19] also pointed that the austenite grain grows a little bit rather than being refined after a $\gamma-\alpha-\gamma$ transformation. The intergranular ferrite and precipitates inside the ferrite grain were the main reason to improve the ductility of the slab. According to dynamic secondary cooling model, water flow of 194.6/1300/4865 $\mathrm{L} / \mathrm{min}$, respectively, in spray zones $1 / 2 / 3$ was given for a cooling rate of around $10{ }^{\circ} \mathrm{C} / \mathrm{s}$ and held at $550{ }^{\circ} \mathrm{C}$ for $\sim 1 \mathrm{~min}$.

In this paper, by taking a sample of a welding structure steel HG785 cast slab from a production line, suitable SSC cooling process parameters were determined by thermal simulation. The effects of different thermal schedules on the ductility of steel were analyzed through tensile experimentation, particularly the effect of the SSC cooling process on the carbonitrides' precipitation distribution, which provides the theoretical basis for surface quality control of microalloyed high strength steel.

\section{SSC Process Test Scheme}

SSC process cooling technology enables the slab to undergo secondary phase transformation to re-austenite structure, to change the location of the carbonitrides precipitation, to form uniform structure, and to improve the ductility of the slab. In order to determine the cooling parameters of the SSC cooling process, a slab of welding structure steel HG785 with high transverse surface cracking susceptibility was selected, the chemical composition of which is given in Table 1 .

Table 1. Chemical composition of Ti-Nb microalloyed steel, wt \%.

\begin{tabular}{ccccccccc}
\hline $\mathbf{C}$ & $\mathbf{S i}$ & $\mathbf{M n}$ & Als & Mo & $\mathbf{C r}$ & $\mathbf{T i}$ & $\mathbf{N b}$ & $\mathbf{N}$ \\
\hline 0.111 & 0.235 & 1.473 & 0.0415 & 0.100 & 0.332 & 0.015 & 0.0318 & 0.0030 \\
\hline
\end{tabular}

The Continuous Cooling Transformation (CCT) curve of HG785 steel calculated by Jmatpro 7.0 (Sente Software, Guildford, UK) is shown in Figure 1. It is shown that the start temperature of ferrite transformation is $829.8{ }^{\circ} \mathrm{C}$ at the equilibrium state, and the region where $\alpha$-ferrite and bainite are formed at a low temperature is staggered at a high cooling rate of $10^{\circ} \mathrm{C} / \mathrm{s}$. The continuous cooling phase transformation of HG785 steel under $1^{\circ} \mathrm{C} / \mathrm{s}$ calculated by Jmatpro is shown in Figure 2 . It is seen that the temperature range of $\gamma \rightarrow \alpha$ phase transformation is in $700-500{ }^{\circ} \mathrm{C}$, and that of $\gamma \rightarrow \mathrm{B}$ phase transformation is in $600-400{ }^{\circ} \mathrm{C}$. 


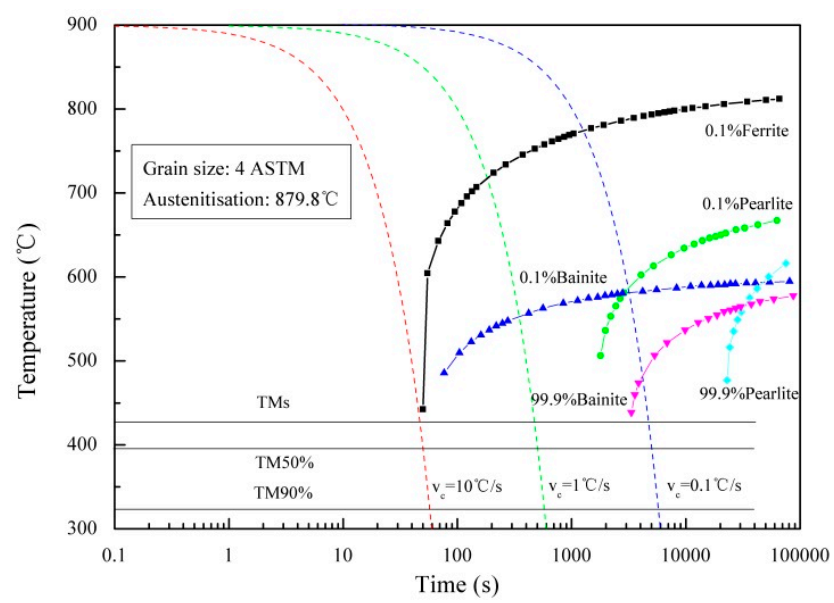

Figure 1. Continous Cooling Transformation (CCT) curve of microalloyed steel calculated by Jmatpro.

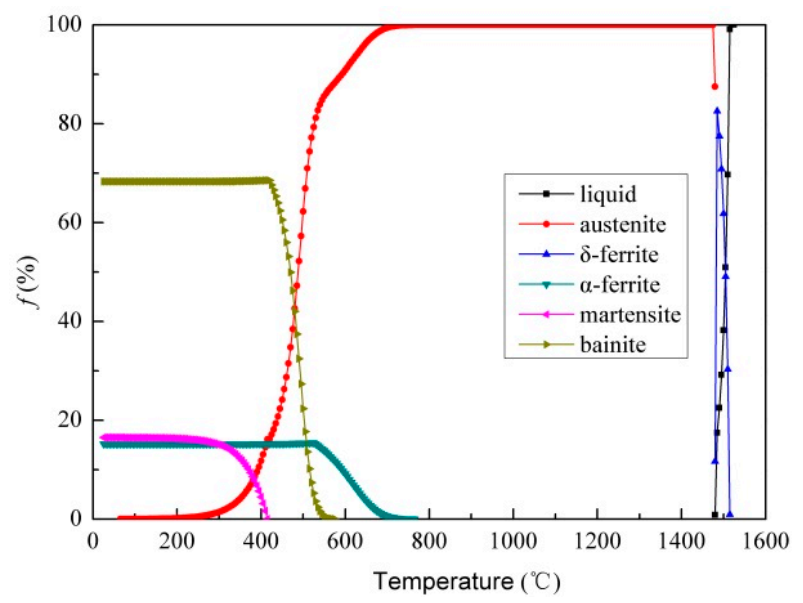

Figure 2. Phase transformation with temperature of microalloyed steel calculated by Jmatpro.

In order to further confirm the SSC cooling process parameters, the phase transformations of microalloyed steels under different thermal schemes were simulated by Gleeble 3500 (Dynamic Systems Inc., New York, NY, USA). The samples were machined into the shape of dumbbell with each end of $10 \mathrm{~mm}$ in diameter and middle of $8 \mathrm{~mm}$ in diameter. To ensure the preservation temperature, the $0 \#$ sample was heated to $1350{ }^{\circ} \mathrm{C}$, held for $5 \mathrm{~min}$, and then cooled to room temperature with a cooling rate of $10^{\circ} \mathrm{C} / \mathrm{s}$. Figure 3 is the measured relative radial expansion $\Delta L / L$ of the $0 \#$ sample, and the linear shrinkage regression equations of steel in the low-temperature phase region and the high-temperature phase region were drawn respectively. According to the lever principle [20], the change of phase transformation $f=|\mathrm{OF}| /|\mathrm{EF}|$ (in volume) of $0 \#$ sample was obtained, shown in Figure 4 . It is shown that the beginning temperature of phase transformation when $f=0.05$ is $573{ }^{\circ} \mathrm{C}$, and the ending temperature of phase transformation when $f=0.95$ is $380{ }^{\circ} \mathrm{C}$. In order to effectively use the thermal resources and ensure the complete phase transformations in the reheating process, the cooling temperature of $600{ }^{\circ} \mathrm{C}$ was adopted, and a certain time of heat preservation was added, which can ensure complete phase transformation. 


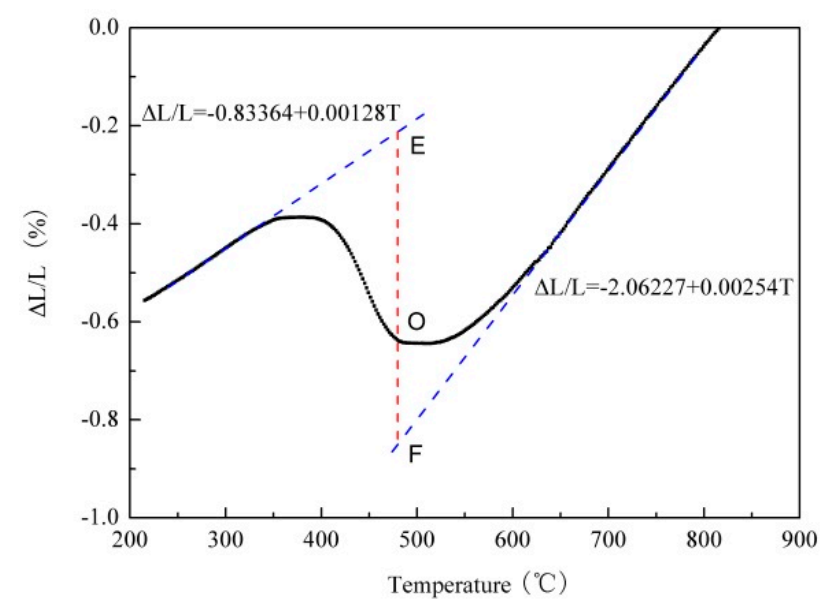

Figure 3. Change of relative radial expansion $\Delta L / L$ with temperature of slab under a continuous cooling rate of $10^{\circ} \mathrm{C} / \mathrm{s}$.

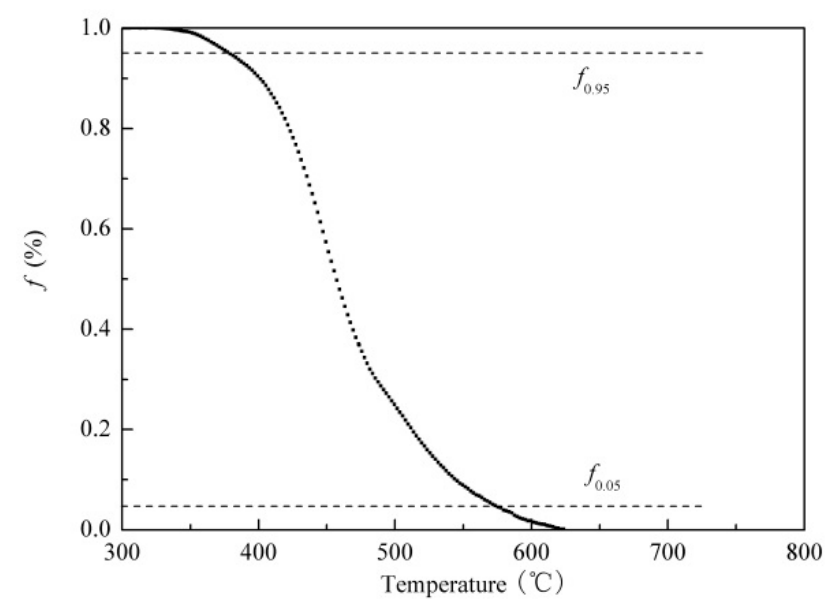

Figure 4. Change of phase transformation $f$ with temperature.

To figure out the preservation time, $1 \#, 2 \#$, and $3 \#$ samples were heated to $1350{ }^{\circ} \mathrm{C}$, held for $5 \mathrm{~min}$, cooled to $600{ }^{\circ} \mathrm{C}$ with a cooling rate of $10^{\circ} \mathrm{C} / \mathrm{s}$, held for $0 \mathrm{~min}, 1 \mathrm{~min}$, and $2 \mathrm{~min}$, and then quenched. The microstructures of the samples after etching ( $4 \mathrm{vol} \%$ nitric acid alcohol) are shown in Figure 5. As shown in Figure 5a, the microstructure of $1 \#$ quenched sample was mainly composed of martensite that was unchanged austenite at a high temperature, and lots of spots distributed around the grain boundary mainly due to the etched pro-eutectoid ferrite. As shown in Figure 5b, the microstructure of 2\# quenched sample was mainly composed of large number of granular ferrite and a small amount of martensite. The microstructure of quenched 3\# sample was mainly composed of acicular ferrite and granular ferrite, but no martensite was observed, which implied complete phase transformation (Figure 5c). When the heat preservation time is $2 \mathrm{~min}$ in the SSC process, the remaining austenite continues to grow during the reheating process, and thus local, abnormally large austenite grains could be avoided. 


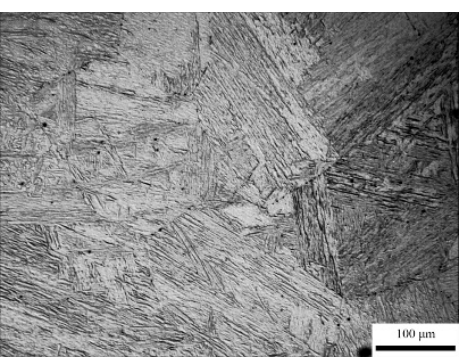

(a) $0 \mathrm{~min}$

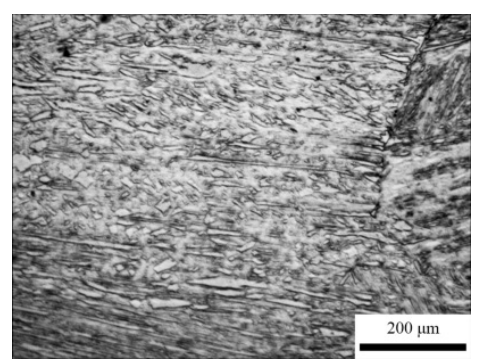

(b) $1 \mathrm{~min}$

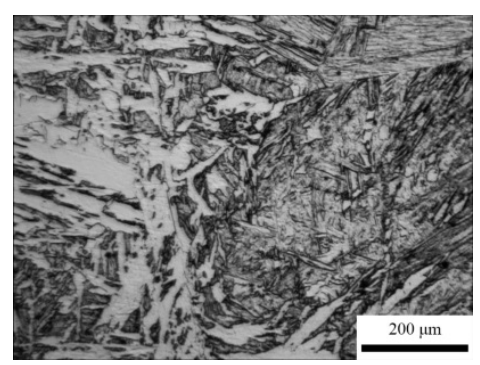

(c) $2 \mathrm{~min}$

Figure 5. Quenching metallographic microstructure of different preservation times at $600{ }^{\circ} \mathrm{C}$ of microalloyed steel.

In the SSC temperature scheme, there is a reheating period mainly due to heat conduction (physical and latent heat) from the core to surface or corner of the slab. Combining previous research [13-18], the reheating rate of $3^{\circ} \mathrm{C} / \mathrm{s}$ is assumed in this paper. $4 \#$ sample was heated to $1350{ }^{\circ} \mathrm{C}$, held for $5 \mathrm{~min}$, cooled to $600{ }^{\circ} \mathrm{C}$ with a cooling rate of $10^{\circ} \mathrm{C} / \mathrm{s}$, held for $2 \mathrm{~min}$, reheated to $1100{ }^{\circ} \mathrm{C}$ with a reheating rate of $3{ }^{\circ} \mathrm{C} / \mathrm{s}$, and then quenched. To determine the reheating temperature, 5\# and $6 \#$ samples were heated to $1350{ }^{\circ} \mathrm{C}$, held for $5 \mathrm{~min}$, cooled to $600{ }^{\circ} \mathrm{C}$ with a cooling rate of $10{ }^{\circ} \mathrm{C} / \mathrm{s}$, held for $2 \mathrm{~min}$, reheated to $1100{ }^{\circ} \mathrm{C}$ and $1000{ }^{\circ} \mathrm{C}$ with a reheating rate of $3{ }^{\circ} \mathrm{C} / \mathrm{s}$, cooled to $800{ }^{\circ} \mathrm{C}$ with a cooling rate of $1{ }^{\circ} \mathrm{C} / \mathrm{s}$, and then quenched. Figure 6 is the microstructures of 4\#, 5\#, and 6\# quenched samples. It is shown that the microstructure is restored to coarse austenite in Figure 6a, and a little amount of ferrite exists because of transformation time within $80 \mathrm{~s}$ in reheating process. As shown in Figure $6 \mathrm{~b}, \mathrm{c}$, the matrix is completely austenite (martensite in quenched sample) owing to a long cooling time. At the same time, the austenite size of quenched sample at $800{ }^{\circ} \mathrm{C}$ was obviously reduced from about $200 \mu \mathrm{m}$ to $70 \mu \mathrm{m}$ when the reheating temperature decreased from $1100{ }^{\circ} \mathrm{C}$ to $1000{ }^{\circ} \mathrm{C}$. Under a same reheating rate of $3{ }^{\circ} \mathrm{C} / \mathrm{s}$, the diffusion coefficient of atoms and the difference of free energy between austenite and ferrite increase with the increase of heating temperature, that makes the phase transformation easier. The transformation time of $6 \#$ sample was $133 \mathrm{~s}$ shorter than that of $5 \#$ sample.

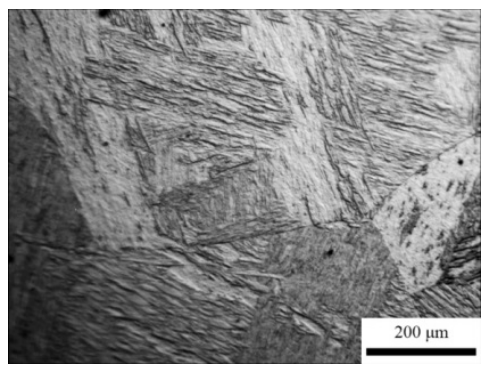

(a)

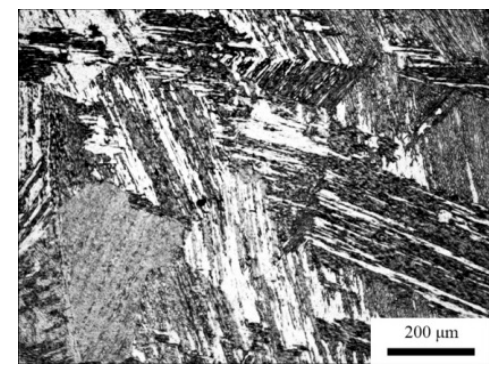

(b)

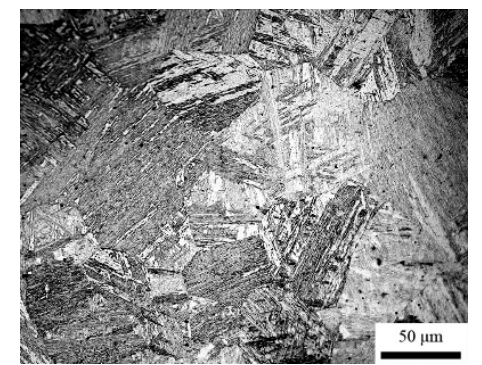

(c)

Figure 6. Quenching metallographic microstructure. (a) 4\# sample, reheating to $1100{ }^{\circ} \mathrm{C}$; (b) $5 \#$ sample, reheating to $1100{ }^{\circ} \mathrm{C}$ and cooling to $800{ }^{\circ} \mathrm{C}$ with $1{ }^{\circ} \mathrm{C} / \mathrm{s}$; and (c) $6 \#$ sample, reheating to $1000{ }^{\circ} \mathrm{C}$ and cooling to $800^{\circ} \mathrm{C}$ with $1^{\circ} \mathrm{C} / \mathrm{s}$.

The temperature schemes of thermal simulation experiments of 0\#-6\# samples of HG785 steel are shown in Figure 7. Based on the results above, the SSC thermal schedule of HG785 steel is as follow: the corner slab at the exit of the mold was cooled to $600{ }^{\circ} \mathrm{C}$ with a cooling rate of $10{ }^{\circ} \mathrm{C} / \mathrm{s}$, held for $2 \mathrm{~min}$, reheated to $1000{ }^{\circ} \mathrm{C}$ with a reheating rate of $3{ }^{\circ} \mathrm{C} / \mathrm{s}$, under a certain condition of spray cooling, the slab enters the straightening process. 


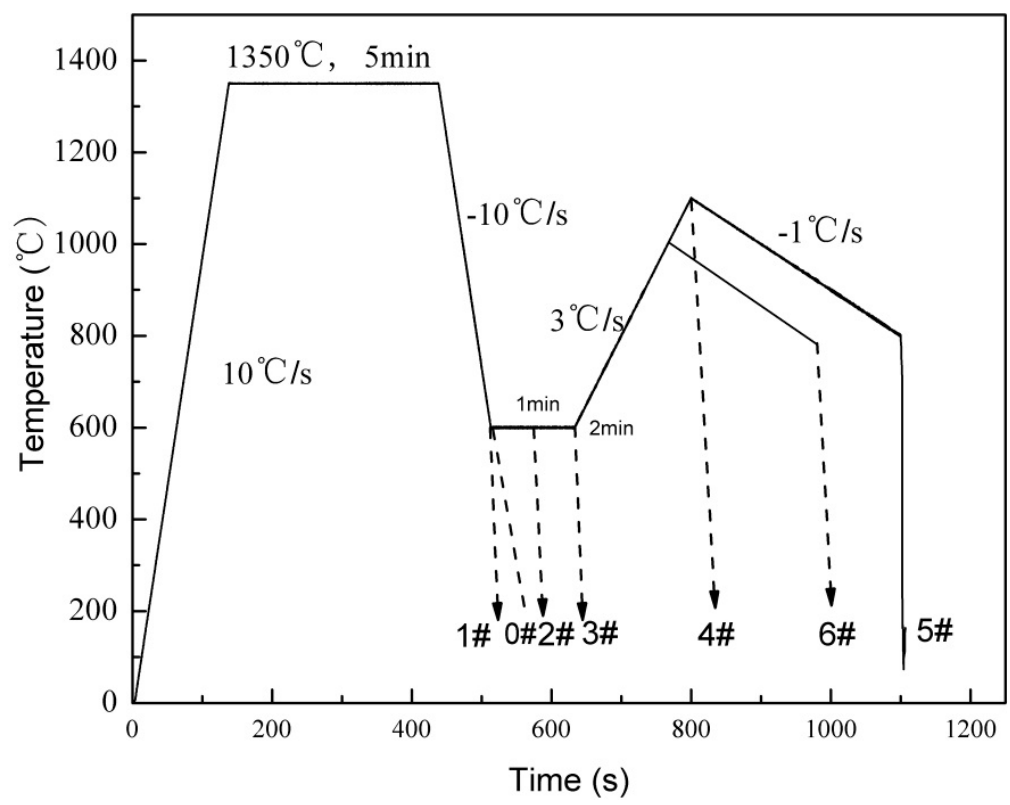

Figure 7. Temperature scheme curves by Gleeble-3500 thermal thermomechanical simulator.

At the same time, in order to better illustrate the law of precipitation in the SSC process, the replicas were examined in JEM-2100F (JEOL, Tokyo, Japan) equipped with an energy dispersive spectrometer. As listed in Figure 8, a small number of precipitates with a size large than $100 \mathrm{~nm}$ are found in the quenched sample after cooled to $600{ }^{\circ} \mathrm{C}$ and held for $2 \mathrm{~min}$, the precipitates were cube in shaped and have been identified as Ti-rich $(\mathrm{Ti}, \mathrm{Nb})(\mathrm{C}, \mathrm{N})$. A certain amount of $10-50 \mathrm{~nm}$ precipitates are observed in the quenched sample after reheating to $1000{ }^{\circ} \mathrm{C}$ and their average metallic elemental composition is $\mathrm{Ti}_{0.53} \mathrm{Nb}_{0.47}(\mathrm{C}, \mathrm{N})$. And a mass of fine dispersed precipitates $(5-20 \mathrm{~nm})$ are formed in the quenched sample after cooling to $800^{\circ} \mathrm{C}$ in the slower cooling process.

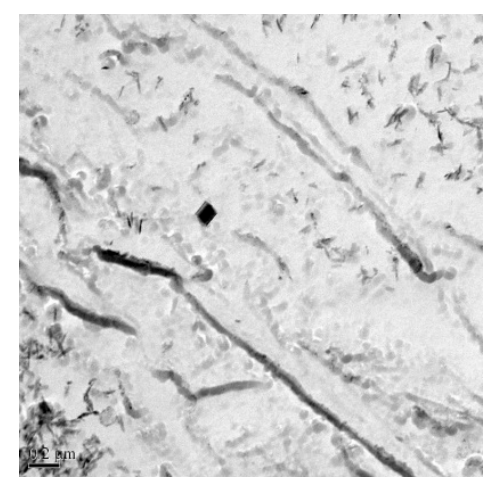

(a)

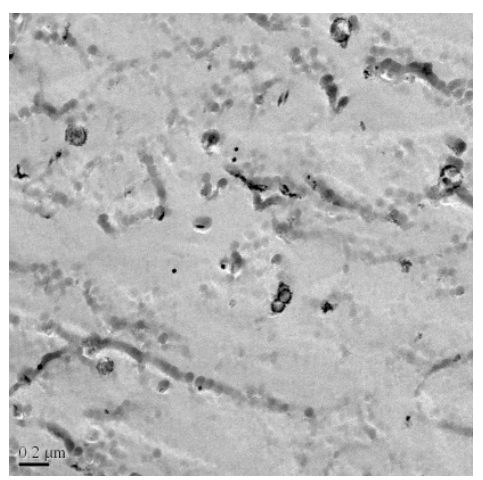

(b)

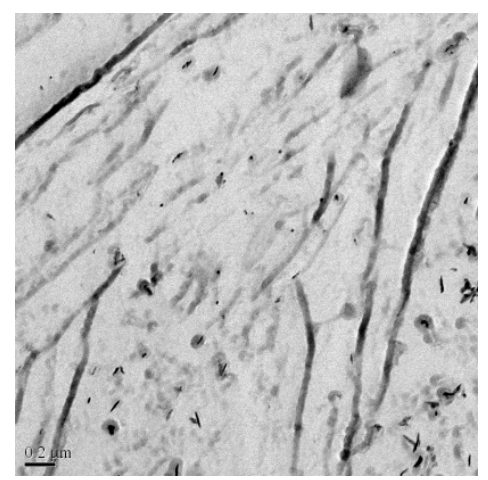

(c)

Figure 8. Typical TEM micrographs of extraction carbon replicas in SSC process (a): cooling to $600{ }^{\circ} \mathrm{C}$ and holding for $2 \mathrm{~min}$; (b): reheating to $1000{ }^{\circ} \mathrm{C}$; (c): cooling to $800{ }^{\circ} \mathrm{C}$ at a cooling rate of $1{ }^{\circ} \mathrm{C} / \mathrm{s}$.

\section{Tensile Tests under Different Thermal Schedules}

Based on the traditional tensile test parameters (pattern 1), the actual continuous casting parameters [21,22] (pattern 2), and the above SSC cooling parameters (pattern 3), the different temperature schemes of tensile tests of HG785 steel by Gleeble 3500 are shown in Figure 9. The tensile samples were machined into $\Phi 10 \mathrm{~mm} \times 120 \mathrm{~mm}$ rods with a thread of M10 × 1.50-6 g. In the temperature schemes shown in Figure 9, the samples were heated at the heating rate of $10{ }^{\circ} \mathrm{C} / \mathrm{s}$ to $1200{ }^{\circ} \mathrm{C}$, and slowly heated to $1350^{\circ} \mathrm{C}$ at the heating rate of $1{ }^{\circ} \mathrm{C} / \mathrm{s}$, held for $5 \mathrm{~min}$, then cooled to the final testing temperature $\left(950-750^{\circ} \mathrm{C}\right)$ with different cooling patterns. The samples were held for 
$1 \mathrm{~min}$ at the target temperature before straining to failure at the slow strain rate of $1.0 \times 10^{-3} \mathrm{~s}^{-1}$. After fracture, the specimens were quenched by high-speed cold compression argon gas to preserve microstructural characteristics and fracture morphology at high temperature. The morphology and the precipitates of fracture samples were observed under Zeiss-Axioplan Optical Microscope (OM, Carl Zeiss, Jena, Thuringia, Germany), Zeiss-EVO Scanning Electron Microscope (SEM, Carl Zeiss, Jena, Thuringia, Germany), and JEM-2100F Transmission Electron Microscopes.

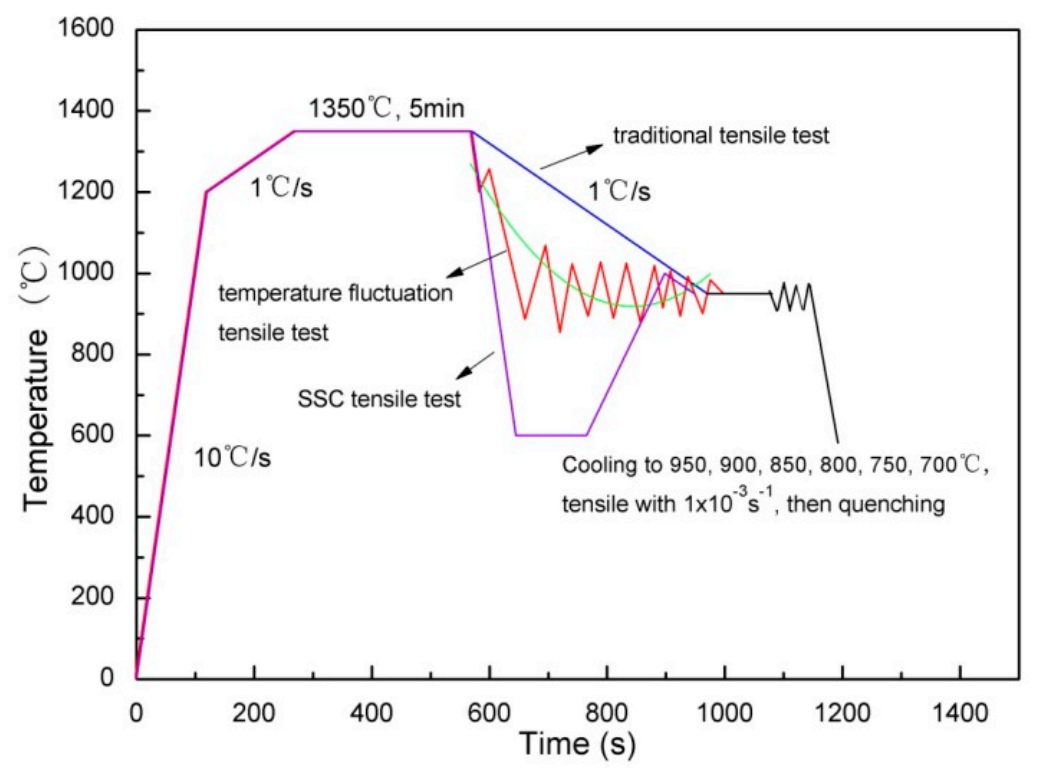

Figure 9. Different thermal schedules for tensile tests.

The results of reduction of area (R.A.) (\%) of the samples under different thermal schedules are shown in Figure 10. The poor ductility in the range of $700-900{ }^{\circ} \mathrm{C}$ exists in both pattern 1 and pattern 2. When the temperature is above $950^{\circ} \mathrm{C}$, all of the three patterns show good ductility. The ductility under pattern 3 has no obvious change, and that may be related to the interaction of austenite size and carbonitride precipitation in SSC cooling preservation. As the temperature goes down, the reductions of area of pattern 1 and pattern 2 reach minimums of $29.7 \%$ and $26.0 \%$ at $800{ }^{\circ} \mathrm{C}$, respectively. As the temperature continues to drop, the ductility under pattern 1 and pattern 2 has recovered in the vicinity of $700{ }^{\circ} \mathrm{C}$ for the emergence of ferrite, however, it is still below the threshold of the brittle area [23]. The R.A. of the SSC samples are higher than $50 \%$ at each test temperature, which shows a low transverse surface cracking susceptibility of slabs with SSC cooling technology during continuous casting.

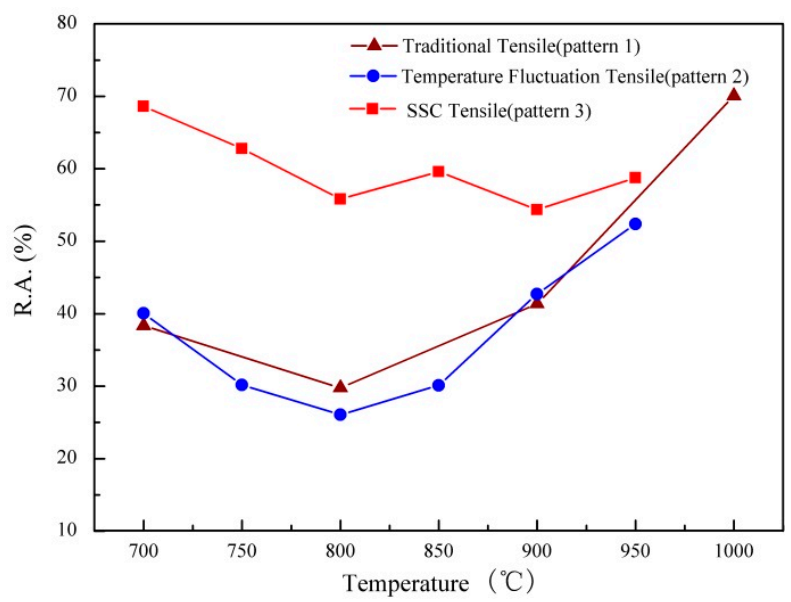

Figure 10. Reduction of area (R.A.) of samples under different thermal schedules. 
Figure 11 represents the tensile fractured morphologies under different thermal schedules of HG785 microalloyed steel. There are lots of deeper toughening nests in the fractured morphologies of the three thermal schedules at $900^{\circ} \mathrm{C}$, as shown in Figure 11a,d,g. The characteristics of the fracture morphologies reveal lots of small toughening nests inside crystals under pattern 3 (Figure 11g) and shallow and large toughening nests under pattern 2 (Figure 11d), both belonging to the trans-crystalline ductility trough. The fracture morphologies of pattern 1 and pattern 2 both show smoother surfaces at $800{ }^{\circ} \mathrm{C}$ (Figure $11 \mathrm{~b}, \mathrm{e}$ ), while a few large and shallow toughening nests exist in Figure 11b, which correspond to a typical brittle fracture. After the SSC thermal schedule, a few shallow toughening nests and tearing fractures are distributed at $800^{\circ} \mathrm{C}$ as shown in Figure $11 \mathrm{~h}$. There are lots of cleavage surfaces and tearing ridges in pattern 1 and 2 at $700^{\circ} \mathrm{C}$, as shown in Figure 11c,f, and dimple fractures appeared under the SSC process (Figure 11i).

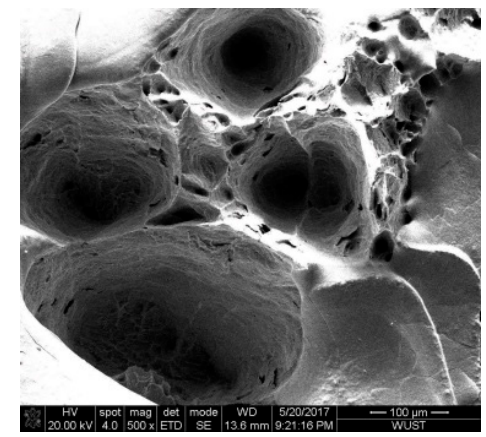

(a) pattern $1-900^{\circ} \mathrm{C}$

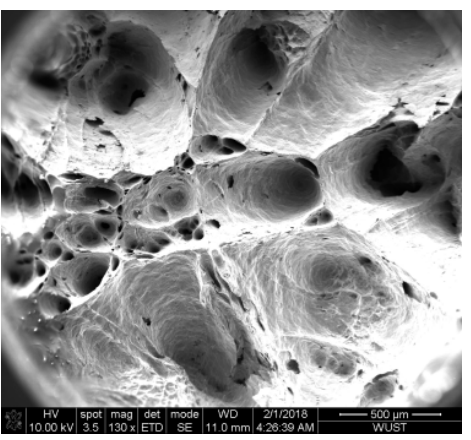

(d) pattern $2-900{ }^{\circ} \mathrm{C}$

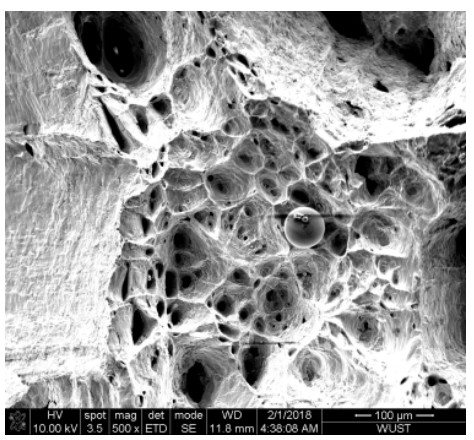

(g) pattern $3-900{ }^{\circ} \mathrm{C}$

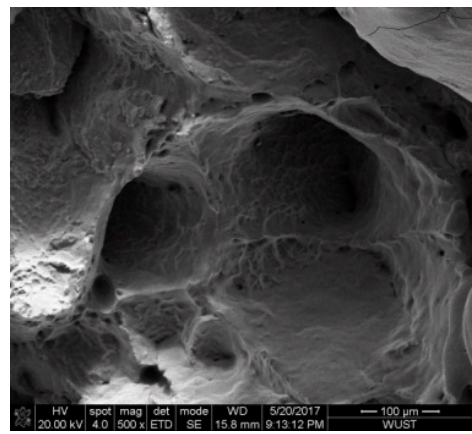

(b) pattern $1-800^{\circ} \mathrm{C}$

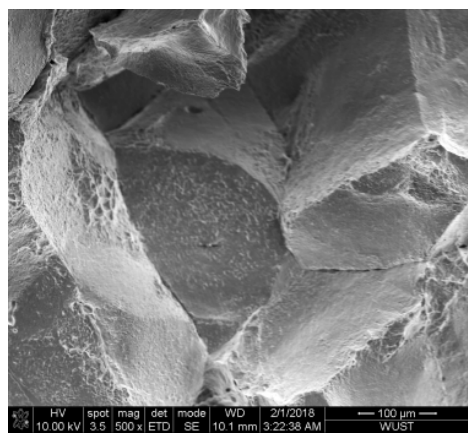

(e) pattern $2-800^{\circ} \mathrm{C}$

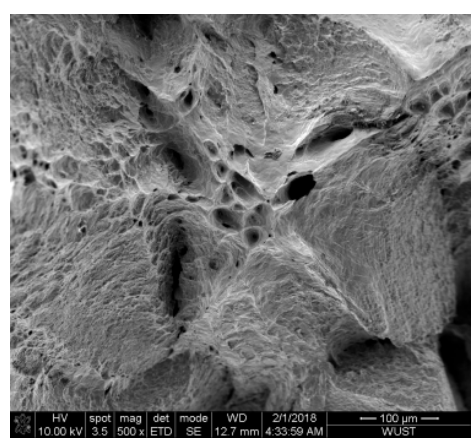

(h) pattern $3-800^{\circ} \mathrm{C}$

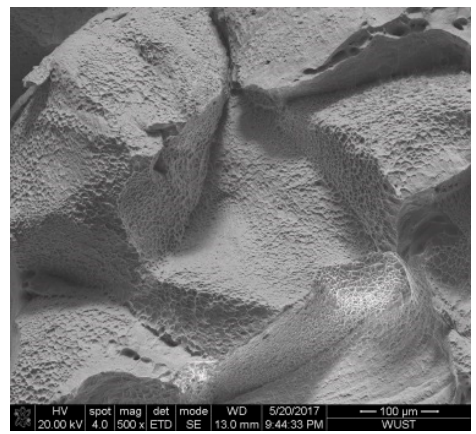

(c) pattern $1-700{ }^{\circ} \mathrm{C}$

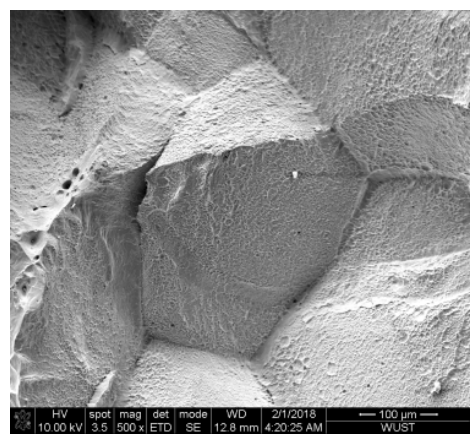

(f) pattern $2-700{ }^{\circ} \mathrm{C}$

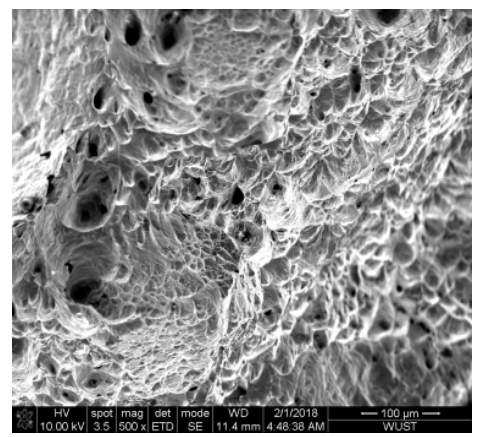

(i) pattern $3-700{ }^{\circ} \mathrm{C}$

Figure 11. Tensile fracture morphology under different thermal schedules.

Figure 12 is the microstructures of fractures under three thermal schedules at $800{ }^{\circ} \mathrm{C}$ by $\mathrm{OM}$. There is lots of martensite and a certain ferrite film (white mesh) in Figure 11a,b. However, after the SSC cooling process, no ferrite film exists around the austenite grain boundary in the etched microstructures at $800{ }^{\circ} \mathrm{C}$, as seen in Figure $12 \mathrm{c}$. 


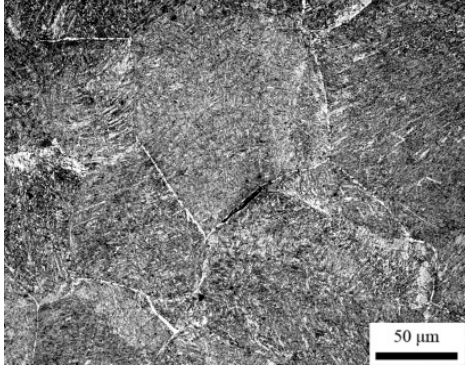

(a) pattern 1

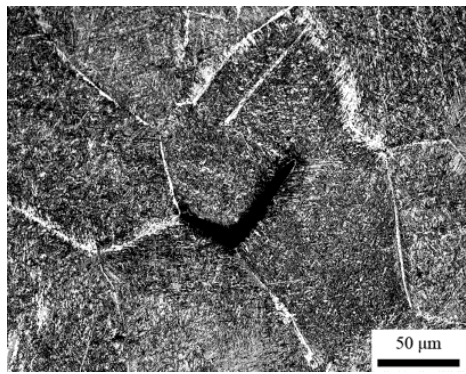

(b) pattern 2

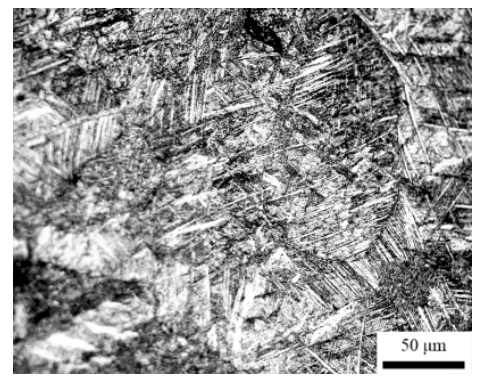

(c) pattern 3

Figure 12. Etched microstructure at $800{ }^{\circ} \mathrm{C}$ under different thermal schedules.

To further compare and analyze the precipitate location and microstructure changes, the microstructures under three thermal schedules at $800^{\circ} \mathrm{C}$ by SEM are shown in Figure 13. As shown in Figure 13a,b, under pattern 1 and 2 thermal schedules, the ferrite films with thickness of 2-3 $\mu \mathrm{m}$ are formed around the grain boundary in the austenite triangle area. The particles $(\sim 100 \mathrm{~nm})$ in ferrite area under pattern 1 are greater in number than in pattern 2. Under the SSC thermal schedule (Figure 13c), there are no ferrite films and aggregated particles formed around the grain boundaries.

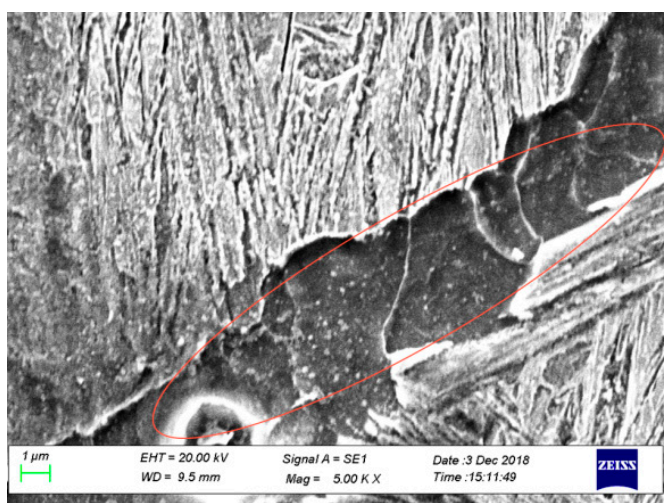

(a) pattern 1

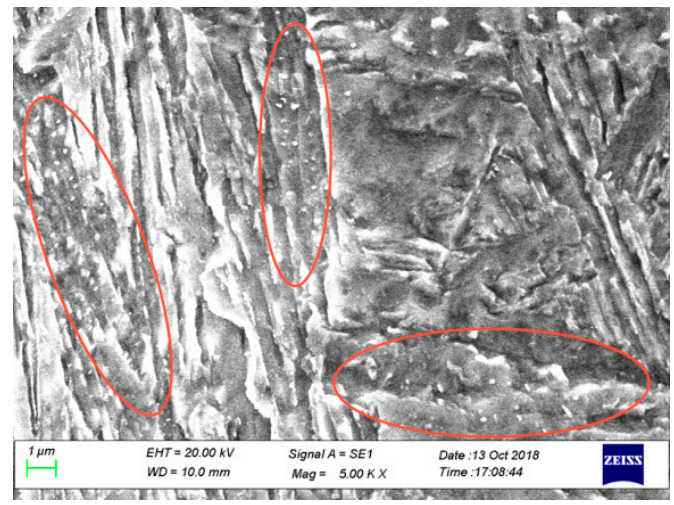

(b) pattern 2

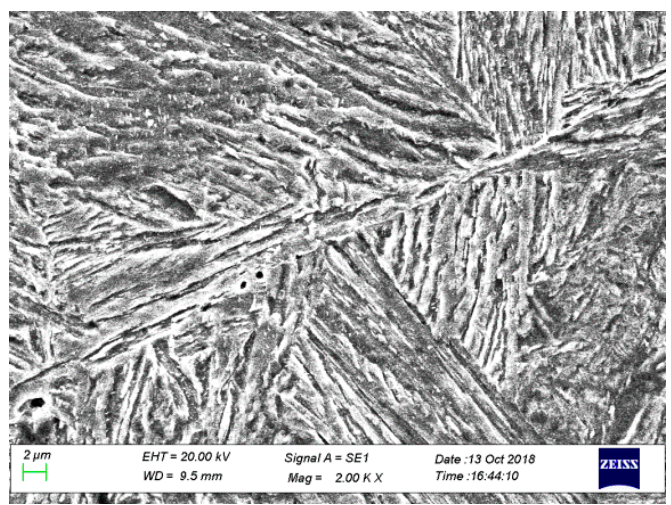

(c) pattern 3

Figure 13. Etched microstructures at $800{ }^{\circ} \mathrm{C}$ observed by SEM under different thermal schedules.

By the aid of Energy Disperse Spectroscopy (EDS, Oxford instruments, Oxford, UK), the morphologies and compositions of precipitates were tested in Figure 14. As shown in Figure 14a, the precipitates under pattern 2 in grain boundary of samples by high resolution SEM mainly consisted of fine rods $\mathrm{Ti}, \mathrm{Nb}(\mathrm{C}, \mathrm{N})$ and matrix $\mathrm{Fe}$, and the average size of precipitates is about $100 \mathrm{~nm}$. As shown in Figure 14b, the morphology of precipitates under pattern 1 by carbon extraction and secondary replication is mainly rectangular or irregular, and the size of precipitates is $50-150 \mathrm{~nm}$. There are a 
large number of fine precipitates $(<50 \mathrm{~nm}$ in size) distributed in chains, which may be around the original austenite grain boundaries. It is inferred that TiN precipitates firstly and then become the nucleation site for precipitates containing $\mathrm{Nb}$ when the temperature decreases [24,25].
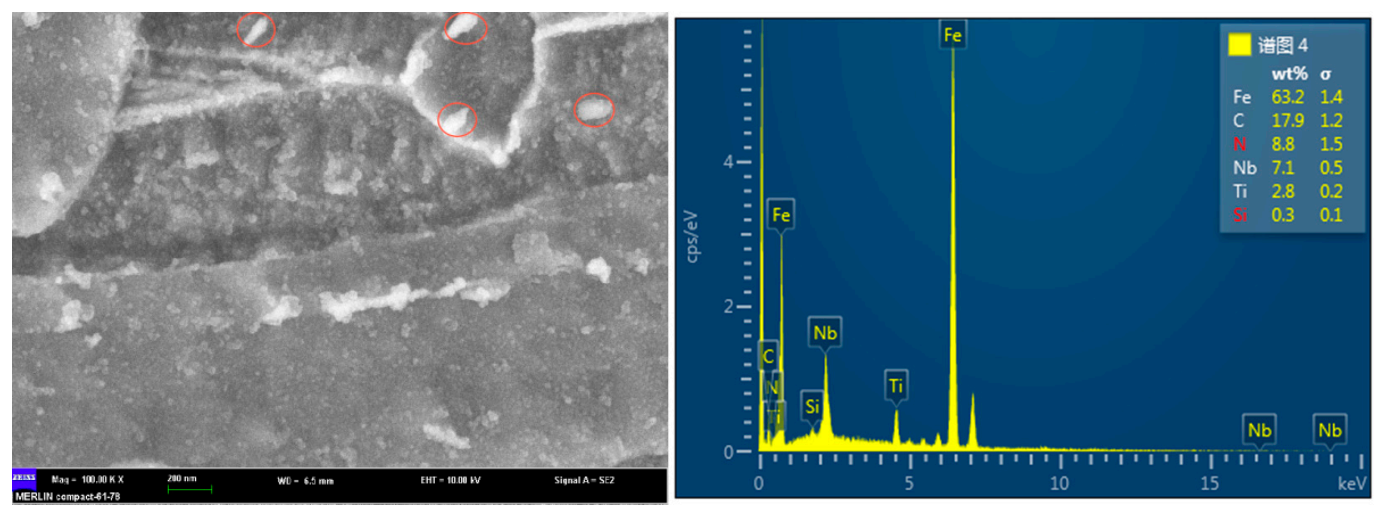

(a) Morphology and compositions of precipitates by SEM and EDS under pattern 2

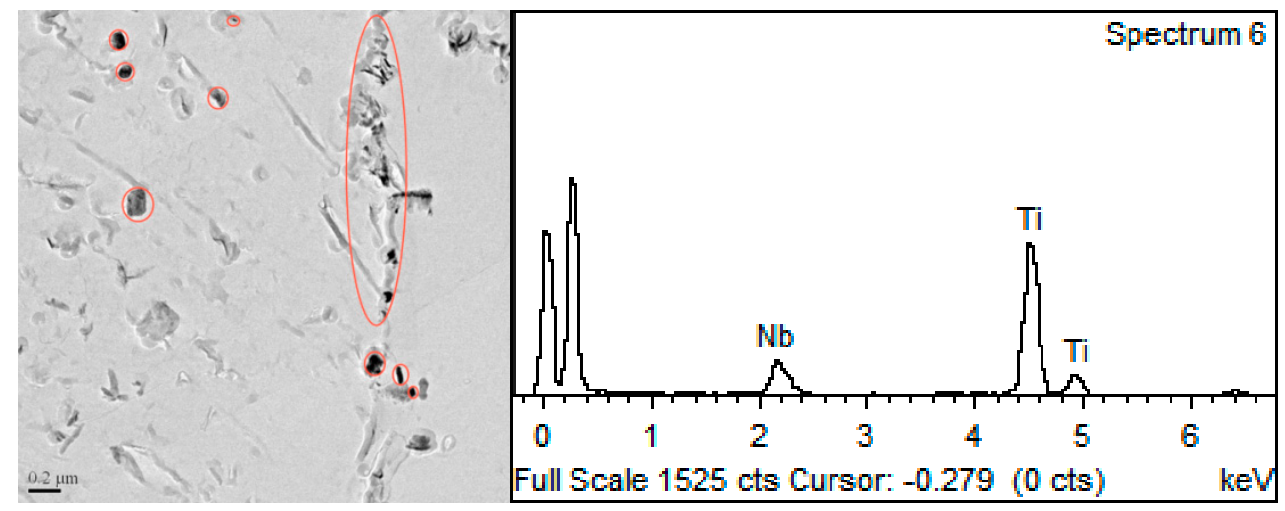

(b) Morphology and compositions of precipitates by TEM and EDS under pattern 1

Figure 14. Morphology and compositions of precipitates under different thermal schedules.

\section{Discussion}

From the above results, it can be seen that $(\mathrm{Ti}, \mathrm{Nb})(\mathrm{C}, \mathrm{N})$ precipitation occurs under different thermal schedules of HG785 microalloyed steel. Combined with previous basic research on second phase precipitation in steel, the works of critical nucleation of the grain boundary and homogeneous nucleation $[26,27]$ under the composition of the tested steel are compared and shown in Figure 15. The critical nucleation work of grain boundary is significantly lower than that of homogeneous nucleation, and the order of homogeneous nucleation work is about $1 \times 10^{-18} \mathrm{~J}$ in the zone of brittleness III. Combined with the second phase precipitation model [28,29], for the $\mathrm{Nb}, \mathrm{C}$, and $\mathrm{N}$ components of the test steel, the precipitation-time-temperature curves of $\mathrm{Nb}(\mathrm{C}, \mathrm{N})$ in austenite are calculated and presented in Figure 16, In the typical "C shape" curves, $t_{0.05}$ and $t_{0.95}$ are the start and finish times of precipitation, respectively. It is shown that the nose temperature for boundary nucleation is $980^{\circ} \mathrm{C}$, and for homogeneous nucleation it is $850^{\circ} \mathrm{C}$. 


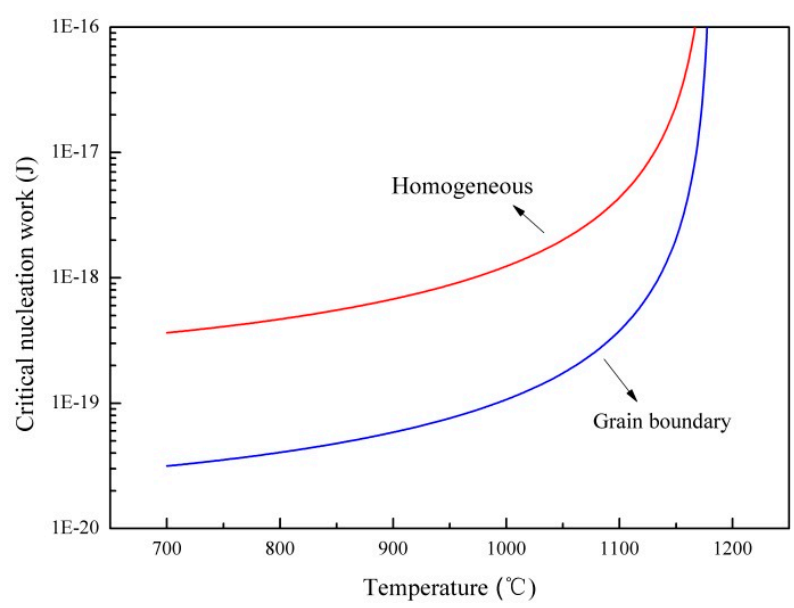

Figure 15. Comparison of nucleation work between grain boundary and homogeneous nucleation.

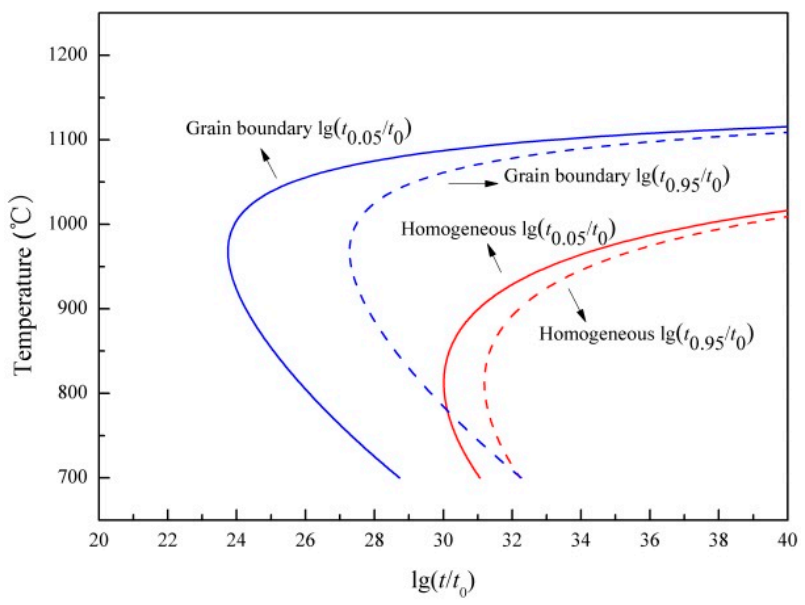

Figure 16. Calculated precipitation-time-temperature (PTT) diagrams of microalloyed steel.

Comparing the influence of three kinds of thermal schedules on ductility of HG785 steel slab in III brittleness area, presented in Figure 17 [30], thin ferrite film will be formed in the brittle trough area $800{ }^{\circ} \mathrm{C}$ under the pattern 1 and pattern 2 thermal schedules. Intergranular failure can occur during the austenite to ferrite transformation when a thin ferrite film has been formed around the austenite grains [31]. Owing to the high stacking fault energy that ferrite has, dynamic recovery can readily take place. The comparative ease of dynamic recovery in ferrite translates into low flow stresses compared with austenite, and therefore the strain concentration is formed in the ferrite film. Lots of $(\mathrm{Ti}, \mathrm{Nb})(\mathrm{C}, \mathrm{N})$ precipitates disperse and grow around the austenite grain boundaries. Those precipitates reduce the bonding force of the grain boundary and hinder the slipping of the grain boundary, and the temperature fluctuation will promote the precipitation of $(\mathrm{Ti}, \mathrm{Nb})(\mathrm{C}, \mathrm{N})$, which can seriously reduce the ductility of steel [14,32]. 


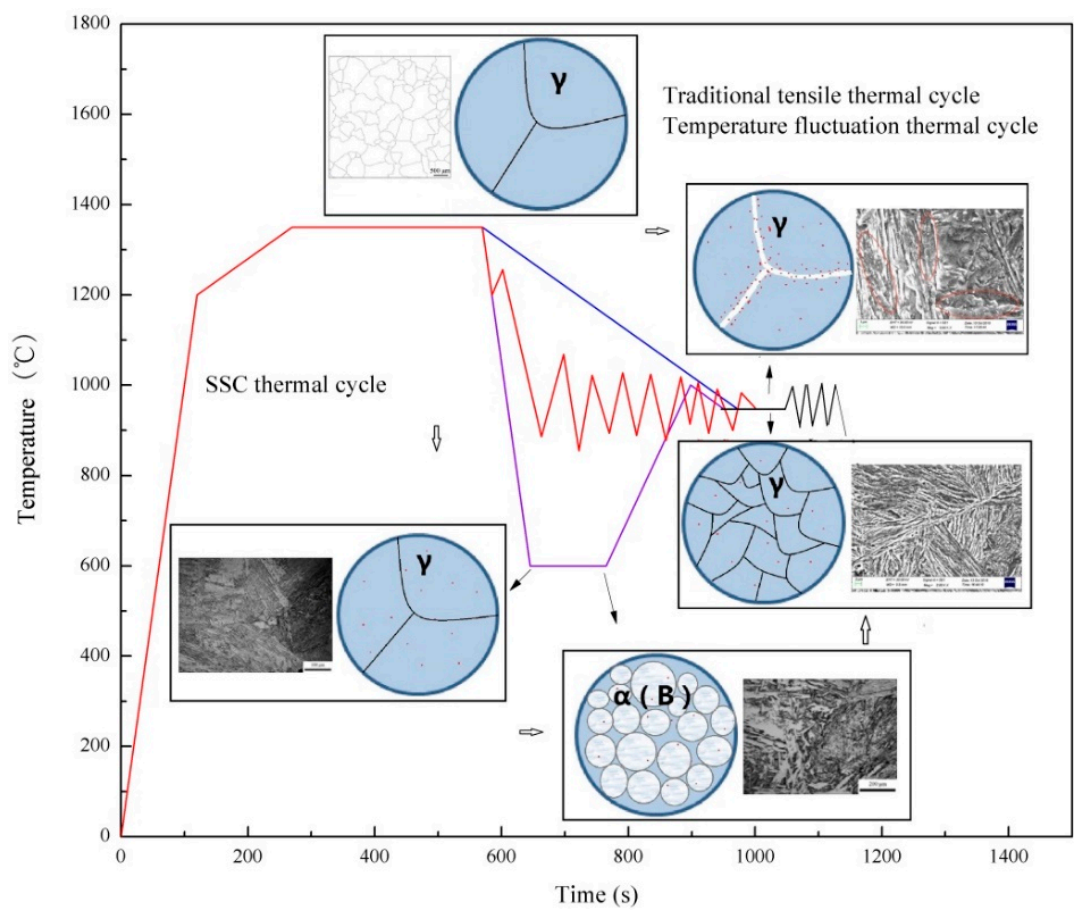

Figure 17. Schematic diagram of the effect of different thermal schedules on ductility.

However, after intense SSC cooling, a large number of microalloyed elements exist in the austenite in the form of solution, and a small amount of tiny carbonitrides are dispersedly precipitated [33]. When the matrix structure changed from austenite to fine ferrite at a low temperature, the microalloyed elements precipitate in ferrite. As shown in Figure 18, because the diffusion coefficient of $\mathrm{Nb}$ and Ti solute elements at $600{ }^{\circ} \mathrm{C}$ is about $10^{3}$ smaller than that of relatively high temperature stage $\left(1350-1100{ }^{\circ} \mathrm{C}\right)$ [26], it is difficult for the precipitates to grow up due to the diffusion limitation of solute elements. At the same time, the growth orientation of ferrite nucleation is greatly different from that of the original austenite grain boundary at a higher cooling rate, and the incubation time of nucleation between grain boundary and in-grain is shortened, which makes ferrite nucleation almost simultaneous in the austenite grain boundary and in-grain, and avoids the formation of ferrite film around the austenite grain boundary at low cooling rates [34]. In the subsequent reheating process, the fine ferrite grains provided a large number of nucleation locations for austenite formation, meanwhile, the dispersed precipitated phase further hindered the growth of austenite grain. Ferrite film and aggregation phenomenon of precipitates around austenite grain boundary has not yet been discovered in original brittleness trough area. The ductility of slab is obviously improved by this kind of secondary phase transformation. 


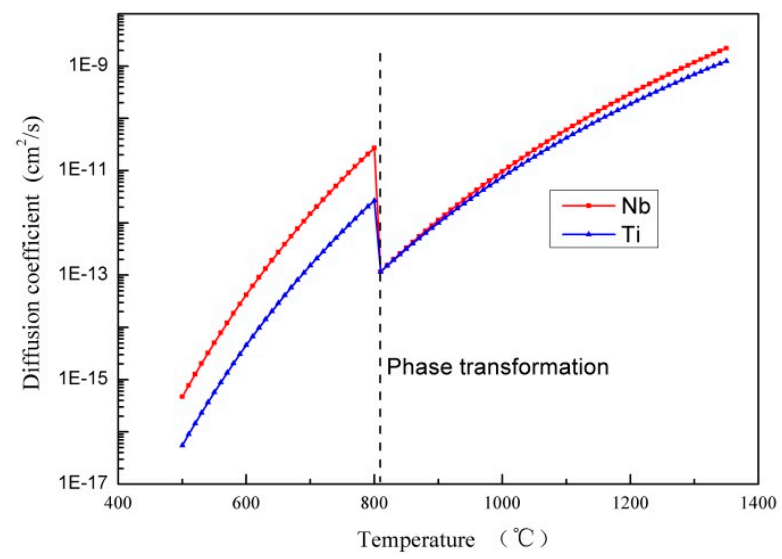

Figure 18. Diffusion coefficient of $\mathrm{Nb}$ and $\mathrm{Ti}$ as a function of temperature.

\section{Conclusions}

(1) Under the intense cooling of $10^{\circ} \mathrm{C} / \mathrm{s}$ in the SSC process, the starting temperature of the $\gamma \rightarrow \alpha$ transformation is $573{ }^{\circ} \mathrm{C}$. Complete phase transformation can be achieved by rapid cooling to $600{ }^{\circ} \mathrm{C}$ and 2 min preservation. When controlling the reheating temperature at $1000^{\circ} \mathrm{C}$, the austenite size is only about $70 \mu \mathrm{m}$ at $800^{\circ} \mathrm{C}$ at a cooling rate of $1^{\circ} \mathrm{C} / \mathrm{s}$.

(2) The poor ductility at $700-900{ }^{\circ} \mathrm{C}$ exists both in the traditional tensile schedule and the temperature fluctuation thermal schedule. Ferrite film with thickness of around 2-3 $\mu \mathrm{m}$ are formed in the trough area of $800^{\circ} \mathrm{C}$, accompanied by a large number of $(\mathrm{Ti}, \mathrm{Nb})(\mathrm{C}, \mathrm{N})$ precipitates of $50-150 \mathrm{~nm}$ around the austenite grain boundary, and the temperature fluctuation will promote the precipitation of $(\mathrm{Ti}, \mathrm{Nb})(\mathrm{C}, \mathrm{N})$, which severely deteriorates the ductility of steel.

(3) In the SSC cooling process, since the grain boundary and the inner nucleation are almost simultaneous, ferrite film along the austenite grain boundary has not yet been discovered, and there is no aggregation of precipitates around the grain boundary due to the diffusion limitation of $\mathrm{Ti}$ and $\mathrm{Nb}$. The ductility of the slab is obviously improved by the secondary phase transformation.

Author Contributions: All authors contributed significantly. L.Y., Y.L., Z.X. and C.C. searched and designed the project. L.Y. and Y.L. performed the data collection, analysis and interpretation. All authors contributed to the discussion of the results, wrote and revised the manuscript.

Funding: This work was funded by National Natural Science Foundation of China (No. 51504172), (No. 51474163).

Conflicts of Interest: The authors declare no conflict of interest.

\section{References}

1. Hong, S.G.; Kang, K.B.; Park, C.G. Strain-induced precipitation of $\mathrm{NbC}$ in $\mathrm{Nb}$ and $\mathrm{Nb}-\mathrm{Ti}$ microalloyed HSLA steels. Scr. Mater. 2002, 46, 163-168. [CrossRef]

2. Tirumalasetty, G.K.; Huis, M.A.V.; Fang, C.M.; Xu, Q.; Tichelaar, F.D.; Hanlon, D.N.; Sietsma, J.; Zandbergen, H.W. Characterization of $\mathrm{NbC}$ and $(\mathrm{Nb}, \mathrm{Ti}) \mathrm{N}$ nanoprecipitates in TRIP assisted multiphase steels. Acta Mater. 2011, 59, 7406-7415. [CrossRef]

3. Jun, H.J.; Kang, K.B.; Park, C.G. Effects of cooling rate and isothermal holding on the precipitation behavior during continuous casting of $\mathrm{Nb}-\mathrm{Ti}$ bearing HSLA steels. Scr. Mater. 2004, 49, 1081-1086. [CrossRef]

4. Karmakar, A.; Sahu, P.; Neogy, S.; Chakrabarti, D.; Mitra, R.; Mukherjee, S.; Kundu, S. Effect of Cooling Rate and Chemical Composition on Microstructure and Properties of Naturally Cooled Vanadium-Microalloyed Steels. Met. Mater. Trans. A 2017, 48, 1581-1595. [CrossRef]

5. Chen, C.Y.; Chen, C.C.; Yang, J.R. Microstructure characterization of nanometer carbides heterogeneous precipitation in Ti-Nb and Ti-Nb-Mo steel. Mater. Charact. 2014, 88, 69-79. [CrossRef]

6. Derda, W.; Wiedermann, J. Some aspects of continuous casting of low carbon micro-alloyed steels with niobium and titanium. Arch. Met. Mater. 2012, 57, 303-310. [CrossRef] 
7. Li, Y.; Wen, G.; Luo, L.; Tang, P. Study of austenite grain size of micro-alloyed steel by simulating initial solidification during continuous casting. Ironmak. Steelmak. 2015, 42, 41-48. [CrossRef]

8. Dippenaar, R.; Bernhard, C.; Schider, S.; Wieser, G. Austenite grain growth and the surface quality of continuously cast steel. Met. Mater. Trans. B 2014, 45, 409-418. [CrossRef]

9. Maehara, Y.; Yasumoto, K.; Tomono, H.; Nagamichi, T.; Ohmori, Y. Surface cracking mechanism of continuously cast low carbon low alloy steel slabs. Met. Sci. J. 2013, 6, 793-806. [CrossRef]

10. Mintz, B. Importance of $\mathrm{Ar}_{3}$ temperature in controlling ductility and width of hot ductility trough in steels and its relationship to transverse cracking. Mater. Sci. Technol. 1996, 12, 132-138. [CrossRef]

11. Jin, Y.; Dong, X.; Yang, F. Removal Mechanism of Microscale Non-Metallic Inclusions in a Tundish with Multi-Hole-Double-Baffles. Metals 2018, 8, 611. [CrossRef]

12. Tsai, H.T.; Yin, H.; Lowery, M. Analysis of transverse corner cracks on slabs and counter measures. Iron Steel Technol. 2006, 3, 23-31.

13. Walmag, G.; Schmitz, A.; Marique, C. A new secondary cooling concept for avoiding surface cracks during casting of peritectic and micro-alloyed steels. In Proceedings of the 4th European Continuous Casting Conference, Birmingham, UK, 14-16 October 2002.

14. Kato, T.; Ito, Y.; Kawamoto, M.; Yamanaka, A.; Watanabe, T. Prevention of slab surface transverse cracking by microstructure control. ISIJ Int. 2003, 43, 1742-1750. [CrossRef]

15. Baba, N.; Ohta, K.; Kato, T. Prevention of slab surface transverse cracking at Kashima caster with surface structure control (SSC) cooling. Rev. Met. 2006, 103, 174-179. [CrossRef]

16. Suzuki, M.; Yu, C.H.; Shibata, H. Recovery of hot ductility by improving thermal pattern of continuously cast low carbon and ultra low carbon steel slabs for hot direct rolling. ISIJ Int. 1997, 37, 862-871. [CrossRef]

17. Lee, U.H.; Park, T.E.; Son, K.S. Assessment of hot ductility with various thermal histories as an alternative method of in situ solidification. ISIJ Int. 2010, 50, 540-545. [CrossRef]

18. Ma, F.J.; Wen, G.H.; Tang, P. Causes of transverse corner cracks in microalloyed steel in vertical bending continuous slab casters. Ironmak. Steelmak. 2010, 37, 73-79. [CrossRef]

19. Du, C.; Zhang, J.; Wen, J.; Li, Y.; Lan, P. Hot ductility trough elimination through single cycle of intense cooling and reheating for microalloyed steel casting. Ironmak. Steelmak. 2016, 43, 331-339. [CrossRef]

20. Gomez, M.; Medina, S.F.; Caruana, G. Modelling of phase transformation kinetics by correction of dilatometry results for a ferritic $\mathrm{Nb}$-microalloyed steel. ISIJ Int. 2003, 43, 1228-1237. [CrossRef]

21. Lückl, M.; Caliskanoglu, O.; Ilie, S.; Six, J.; Kozeschnik, E. Impact of Surface Structure Control Cooling During Continuous Casting on Hot Ductility of Microalloyed Steel. Steel Res. Int. 2016, 87, 871-879. [CrossRef]

22. $\mathrm{Xu}, \mathrm{K}$; Thomas, B.G. Model of Microalloy Precipitation during Continuous Casting and Reheating. In Proceedings of the AISTech 2011 Conference, Indianapolis, IN, USA, 2-5 May 2011.

23. Yamanaka, A.; Nakajima, K.; Okamura, K. Critical strain for internal crack formation in continuous casting. Ironmak. Steelmak. 1995, 22, 508-512.

24. Luo, H.; Pentti Karjalainen, L.; Porter, D.A. The Influence of Ti on the Hot Ductility of Nb-bearing Steels in Simulated Continuous Casting Process. ISIJ Int. 2002, 42, 273-282. [CrossRef]

25. Qian, Q.; Cheng, G.C.; Hou, Z.B. Effect of the Induced Ferrite and Precipitates of Nb-Ti Bearing Steel on the Ductility of Continuous Casting Slab. ISIJ Int. 2014, 54, 1611-1620. [CrossRef]

26. Yong, Q.L. Secondary Phases in Steels; Metallurgical Industry Press: Beijing, China, 2006. (In Chinese)

27. Moon, J.; Lee, C. Behavior of $(\mathrm{Ti}, \mathrm{Nb})(\mathrm{C}, \mathrm{N})$ complex particle during thermomechanical cycling in the weld CGHAZ of a microalloyed steel. Acta Mater. 2009, 57, 2311-2320. [CrossRef]

28. Weiss, I.; Jonas, J.J. Interaction between recrystallization and precipitation during the high temperature deformation of HSLA steels. Met. Trans. A 1979, 10, 831-840. [CrossRef]

29. Park, J.S.; Ha, Y.S.; Lee, Y.K. Comparison of Experimental Methods to Measure the Isothermal Precipitation Kinetics of $\mathrm{Nb}(\mathrm{C}, \mathrm{N})$ in Austenite of a $\mathrm{Nb}-$ Microalloyed Steel. Met. Mater. Trans. A 2009, 40, 1515-1519. [CrossRef]

30. Yang, L.; Li, Y.; Xue, Z.L.; Cheng, C.G. Influence of Ti(C,N) precipitates on austenite growth of micro-alloyed steel during continuous casting. China Foundry 2017, 14, 421-428. [CrossRef]

31. Akhlaghi-Esfahani, S. Effect of a Thermomechanical History on the Hot Ductility of a Nb-Ti Microalloyed Steel and a Low Carbon Steel; McGill University: Montreal, QC, Canada, 2000.

32. Maehara, Y.; Ohmori, Y. The precipitation of $\mathrm{A} 1 \mathrm{~N}$ and $\mathrm{NbC}$ and the hot ductility of low carbon steels. Mater. Sci. Eng. 1984, 62, 109-119. [CrossRef] 
33. Stock, J. NbC and TiN Precipitation in Continously Cast Microalloyed Steels; Colorado University: Denver, CO, USA, 2014.

34. Liu, J. Study on the Effect of Ferrite on the Austenite Grain Refinement for Hypoeutectoid Microalloyed Steel during Continuous Casting; Chongqing University: Chongqing, China, 2017. (In Chinese)

(C) 2019 by the authors. Licensee MDPI, Basel, Switzerland. This article is an open access article distributed under the terms and conditions of the Creative Commons Attribution (CC BY) license (http:/ / creativecommons.org/licenses/by/4.0/). 